\title{
Coronavirus and beyond: empowering social self-organization in urban food systems
}

\author{
Andrea Calori ${ }^{1} \cdot$ Francesca Federici ${ }^{1}$
}

Accepted: 28 April 2020 / Published online: 14 May 2020

(c) Springer Nature B.V. 2020

In the city of Milan, Italy, the first restrictions on the activities and movement of people took place on February 24 and the national lockdown was decided on March 8 . Since Italy was the first European nation to officially recognize the presence of Coronavirus (while it is now clear that the virus has been circulating in Europe since at least January), there has been very little time to prepare individually and collectively to deal with impacts of the lockdown and without being able to compare with other experiences of countermeasures to counteract the effects of the virus on access to food.

In this situation of rapid change, individual solutions and neighborhood micro-networks have often made up for the sudden lack of what allows a product to reach citizens: knowledge, organization, transport, communication, etc. What happened in Milan and in other Italian cities is the rapid growth of organizations based on families of the same condominium, parishes, associations and informal networks that have autonomously managed to collect needs, to contact food producers or processors and to co-organize distribution and payments.

These social organizations have guaranteed the supply of food by implementing approaches that are complementary or alternative to the usual ones and this also in the case of people or social actors who previously did not specifically dedicate themselves to food. The strength of social ties even beyond issues strictly related to food, shows how these ties can fulfill some tasks that, in our societies, are assigned to the market. This approach has proven to be able to respond to even a very strong shock in a much more flexible way than most market players. It should also be considered that these experiences developed outside any kind of public support

This article is part of the Topical Collection: Agriculture, Food \& Covid-19.

Andrea Calori

andrea.calori@assesta.it

1 EStà - Economia e Sostenibilità, Milano, Italy and having, in fact, almost only supermarkets as the only consolidated channels of food supply that were legitimized by the norms or that were able to maintain standards of social distancing and adequate logistics.

Many of these social experiences cannot replace the entire current socio-economic organization and they are not necessarily optimal in terms of costs and employment, but they have also been a solution for those many shops (bakeries, vegetable shops, butchers, etc.) which constitute a widespread basis on which a large part of the Italian culinary tradition rests but which are not linked to networks of organized consumers and which often depend on a macrologistica that they do not control. In fact, many small and mediumsized stores have slowly reopened after many weeks, relying on these networks of citizens, and the ability of the "demand side" to organize parts of the food system has allowed the maintenance of a certain vitality also on the supply side.

Those who managed to face the situation in a better way are the people who previously made individual choices in favour of sustainable lifestyles (rationalization of consumption, reduction of waste, recycling, local purchases, limited intermediation, etc.) and, above all, those who were already part of networks organized for the purchase of food such as, for example, solidarity economy networks, Community Supported Agriculture, consumer cooperatives, local consortia, etc.

All this teaches us that, for access to food, lifestyles are not to be traced only to the sphere of the "private" or the "individual", or to be separated or opposed to the public or to the market dimension, but they are part of the structural aspects of our society and economy and, as such, they should be recognized and valued as part of public policies and in the different forms of what we call "the market".

The question that arises now is how to multiply the positive effects of solutions that have shown themselves to be flexible and which, in addition to satisfying the need for food, have allowed us to respond to other needs that are connected to food (sociability, health, wellness, etc.). I am 
thinking, for example, about the combination of different policies and services such as: an increase in digital services as part of supporting new forms of sociality; a set of services and neighborhood-scale structures connected to sustainable mobility systems for the redistribution of surplus food to people in difficulty as part of the local welfare; recognition of solidarity-based networks, microcredit; local food hubs, etc. All this to be thought of through the integration of waged and voluntary work and new forms of social impact enterprises.

To do this, active rules and policies are needed to move from the mainstream market towards social solutions that have proven to be more adequate and flexible, in a "new alliance" between sustainable lifestyles and the so-called "structural policies": even beyond Coronavirus.
Publisher's Note Springer Nature remains neutral with regard to jurisdictional claims in published maps and institutional affiliations.

Andrea Calori President of EStà, $\mathrm{PhD}$ expert in territorial policies, local development and governance of sustainable food systems, since the early ' 90 s he has been working with local, national and international institutions (OECD, EU Commission, Council of Europe, FAO, UNDP, etc.), for ten years contract professor at Politecnico di Milano.

Francesca Federici Expert in sustainable food systems, circular economy and indicators of sustainability, member of the Board of EStà an independent and non-profit research centre that works on a systemic approach to sustainability, responsible of the methodologies and the researches supporting the Food Policy of Milan. 